This article was downloaded by: [University of Sydney]

On: 04 May 2015, At: 20:16

Publisher: Routledge

Informa Ltd Registered in England and Wales Registered Number: 1072954

Registered office: Mortimer House, 37-41 Mortimer Street, London W1T

3J H, UK

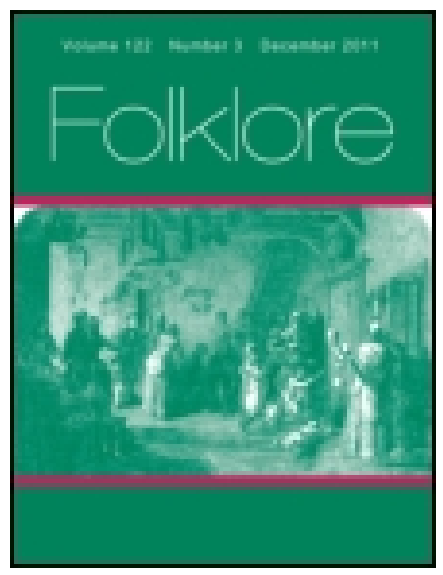

\title{
Folklore
}

Publication details, including instructions for authors and subscription information:

http:// www. tandfonline.com/loi/ rfol20

\section{Scraps of English Folklore, III}

The Late E. J. Ladbury \& S. O. Addy

Published online: 14 Feb 2012.

To cite this article: The Late E. J . Ladbury \& S. O. Addy (1909) Scraps of English Folklore, III, Folklore, 20:3, 342-349, DOI: 10.1080/0015587X.1909.9719892

To link to this article: http:// dx. doi. org/ 10.1080/0015587X.1909.9719892

\section{PLEASE SCROLL DOWN FOR ARTICLE}

Taylor \& Francis makes every effort to ensure the accuracy of all the information (the "Content") contained in the publications on our platform. However, Taylor \& Francis, our agents, and our licensors make no representations or warranties whatsoever as to the accuracy, completeness, or suitability for any purpose of the Content. Any opinions and views expressed in this publication are the opinions and views of the authors, and are not the views of or endorsed by Taylor \& Francis. The accuracy of the Content should not be relied upon and should be independently verified with primary sources of information. Taylor and Francis shall not be liable for any losses, actions, claims, proceedings, demands, costs, expenses, damages, and other liabilities whatsoever or howsoever caused arising directly or indirectly in connection with, in relation to or arising out of the use of the Content.

This article may be used for research, teaching, and private study purposes. Any substantial or systematic reproduction, redistribution, reselling, loan, sub-licensing, systematic supply, or distribution in any form to anyone is 
expressly forbidden. Terms $\&$ Conditions of access and use can be found at http://www.tandfonline.com/page/terms-and-conditions 
let it cook by the heat of the mid-day sun. They also observed that the barbs were neatly fastened on to his spears with gum, and that all his weapons were better finished than those of other people. Repeated inquiries as to how he managed all these things elicited nothing definite, and consequently the pigeon, wath, and the sparrowhawk, kurringar, were appointed to watch him when out hunting. About the middle of the day they saw smoke rising from where he was camping, and, as they could not make out what it was, they stole upon him unawares. As soon as the bandicoot saw them he commenced putting the fire into the usual receptacle; but the sparrowhawk, who was always very quick in his movements, made a sudden rush and secured some of it, with which he set fire to the surrounding bush. Every tree, from the hardest to the softest, got a share of the fire, and from them the blacks have obtained it ever since.

Why Lakes are Salt.-The natives of the Kimberley district of Western Australia believe that a supernatural monster, in serpent form, made all the rivers as he travelled inland from the sea. The big waterholes which occur along the courses of the rivers are places where he rested at night. Once he camped for a long time at the shallow lake into which the Sturt Creek empties, and it is owing to his urine that the water there is saline. The saltness of other lakes in that part of the country is ascribed to the same cause. This creature is known as Ranbal in some localities, and as Wonnaira in others.

Parramatta, N.S. Wales.

R. H. Mathews.

\section{Scraps of ENGLISH FolkLoRE, III.}

Worcestershire.

The following items were collected from servants, old residents, school children, etc., in the neighbourhood of Hartlebury during the years 1900-1, except when another date is affixed.

"Crop your hair in the moon's wax,

Ne'er cut it in her wane,

And then of a bald head

You never shall complain." 
You should turn the money in your pocket when you see the new moon, and it is good luck if you also have a knife in your pocket.

At the first new moon in the New Year, you should hold up a new silk handkerchief by the two corners, and, as many moons as you see through the handkerchief, so many years will pass before you are married.

For divination of your future lover, say,-"New moon, new moon, in the bright firmament, if - is my true love to be, let, the next time I see him, his face be turned towards me."

If you find a leaf of the common ash with the terminating leatlets even, it will bring "luck or a lover."

It is most unlucky to transplant parsley.

Never kick fungi with your foot, or you will have bad luck for seven years.

It is unlucky to bring the following into the house:- snowdrops before the frst chickens are hatched; broom in blossom in the month of May'; hawthorn before May; and mistletoe before Christrnas.

All children who either gather or eat blackberries on or after the isth of Octaber will fall into great trouble. It is said that "the Devil puts his paw on them" on that day."

It is unlucky to keep Christmas holly about the house after Candlemas Day, as the Evil One will then come himself and pull it down.

If a sprig of Christmas holly is thrown on the fire and burns with a crackling noise, it is a sign of good luck; but, if it burns with a dull flame and does not crackle, it is a sign of a death in the family within the year.

It is unlucky to burn elder wood. An old inhabitant of Hartlebury will not allow a piece to be put on the fire. ${ }^{8}$

At Iartlebury it is believed that, if a gooseberry or currant bush dies or shrivels up when covered with fruit, there will be a death in the family of the owner before the year is out $(2891)$.

'Cf. The Folk-Lore Kecord, vol, j., p. 52 (Weat Sussex).

"October roth is Old Michaelmas Day. Cf. The Folk-Lora Record, vol. i.,

p. 14 (West Sussex).

"Ct. vol. vii, p. 380 (Staffordshire).। 
A rose of which the flower has any green sepals mixed with the red petals is called a "death rose," and is an omen of death to one of the family. The same omen is derived from a tree bearing ripe apples and blossoms at the same time.

The following are other death omens:-A white bird flying against or in front of a window; a cat dying in the house (1897); a bat flying against a window; a mole coming near a house; and rats nibbling furniture.

It is an extremely bad omen if a ringer "throws" a bell when ringing a wedding peal, or if a bell rope breaks.

If a bell is rung while the clock is striking you will shortly hear of a death.

A clock falling is a sign that the death of some one belonging to the family has taken place at the same moment.

If you drop a pair of scissors and they stand up on their double point, you will hear of a wedding, but, if only on one point, it is a sign of a death.

A humble bee flying towards the house is a sign of a stranger coming, or of a death.

A robin looking into a room causes good luck.

A cat scratching the leg of a table is a sign of rain, and, if she washes her face with her left paw over her left ear, it is a certain sign of snow.

A toad crossing the road is a sign of rain.

To kill a beetle will cause rain. ${ }^{4}$

If the crust of a boiled apple pudding breaks when being turned out of the basin, it is a sign of a wet week. (I think this applies especially to a Sunday pudding.)

"If the cock goes crowing to bed,

It's a sign he will rise with a watery head,"

i.e. that the next morning will be wet.

If the moon is either new or full on a Saturday it always brings bad weather, and often a flood.

"Saturday"s new and Sunday's full, Always brought rain and always wull."

4Cf. "Folk Lore in Ilull," Notes and Qurries, vol. vi. (1852), p. $3^{\text {ts. }}$ 
The snow won't stay after Candlemas Day.

In the quarter from which the wind blows on Candlemas Day it will remain until May.

If the wind is in the east at noon on St. Benedict's Day (March 2rst), it will neither chop nor change till the end of May.

The first person of the opposite sex you meet on New Year's Day will rule you throughout the year.

It is customary in some parts to make up the fire both on Christmas Eve and on New Year's Eve, and keep it burning through the night.

It is bad luck to throw soap suds out of the house on Froly Thursday.

If you hang clothes out to dry on Holy Thursday there will be a death in the family, and the corpse will be laid out in some of the clothes. ${ }^{3}$

If you open an umbrella in the house and hold it over your head, there will be a death in the house before the year is out.

If you drop your umbrella you must not pick it up yourself, but ask some other person to do so, or you will meet with a disappointment.

To drop a spoon means disappointment.

It is lucky to tread on any piece of iron with your right foot.

It is good luck for a stranger to poke the house fire. ${ }^{\circ}$

If a fire burns hollow or burns brightly on only one side of the grate, there will be a wedding in the family.

A bride should never see her reflection in a looking-glass after being fully dressed for her wedding.

If you have a pin out of a bride's veil you will soon be a brite yourself?

It is good luck to give a crooked pin.

The gift of a brooch breaks love between friends.

It is very unlucky for tzoo people to pour out tea from the same teapot at one meal; to look in the oven when anything is baking; or to get over a stile at the same time $(1887)$.

\footnotetext{
"Cf. Yarkshire, infra.

"Cf. Burne, Shropshiva Folktore, p. 21 \%.

'Cf. The Folk-Lore Kecord, vol, i, p. 33 (West Sussex).
} 
Two persons washing their hands in the same water should make the sign of the cross on the water, or they will quarrel. ${ }^{8}$

Quarrels will be caused by sitting in a room with three candles burning, or with the poker and tongs on the same side of the fireplace.

To say goodbye at a gate foretells that you will be parted from your friend (1895).

To go back over your doorstep for anything forgotten is unlucky; you should sit down to break the spell.

Red worsted wound nine times around the wrist is in constant use for the cure of sprains.

If you have the hiccough, drink nine times round a cup and it will leave you.

Cut all your nails before twelve o'clock on Good Friday, but never cut them on any other Friday in the year, and you will not have toothache.

If you put your left stocking on before your right, every morning, you will not have toothache.

If you find a left-hand glove, leave it lying where it is, or it will bring sorrow,

If you have clothes mended on your back, you will have lies told about you."

The clothes of the dead will not wear long.

There is a common saying in this part of Worcestershire, if any garment is hopelessly dirty, that "it is as black as the Devil's nutting bag." 10

If an infant is christened with the same name as that borne by an elder brother or sister, the child will die.

If several children are brought to the christening font together, care must be taken that the boys are baptized first, as otherwise, when they grow up, the boys will have smooth faces and the girls will have beards, 11

If an eyelash falls out, put it on the back of the hand, and wish, and the wish will come true.

"Cf. "Folk Lore in IIull," Notes and Qutries, vol, vi. (1852), p. $3^{11 .}$

"Cf. The Folk-Lore R'ecord, vol. i., p. 12 (West Sussex),

${ }^{10} \mathrm{Cf}$. The Folk-Lore Record, vol. i., p. $1_{4}$ (West Sussex).

"Cf. Notes ana' Querics, tst S., vol. i. (1850), p. 197 (north of England) 
There is a "wishing well" at Abberley, near Kidderminster. The mode of "wishing" is to walk three times round the well, dropping a little pebble into its basin at each turn, and at the same time whispering your wish.

A newt is much disliked. It is called a hasgill, and supposed to possess some poisonous property. In Hartlebury, in 5890 , a workman positively refused to whitewash a portion of a cellar in which he had discovered some very small newts, saying that he would not do it, as there were hasgills on the floor. When "asked what harm they could do him, he exclaimed with horror, "Why, they'm pison," and nothing would induce him to finish the work.

Dobe's Barn, sittated in Dobe's Lane, Chaddesley Corbett, has always had an evil reputation as haunted, many people objecting to pass it after dark.12

The belief in fairies has not yet died out in Worcestershire. An intelligent working-man, just past middle age, told me in 1897 many anecdotes about them. When a lad he lived with his father, a small farmer, on the edge of the Forest of Wyre, and went ont with the horses. His bedroom was over the pantry, and near the stable. He declared that at night things were thrown about in the pantry, crockery rattled violently, etc., but that in the morning everything was in its proper place. He scomed the suggestion of rats. The horses used to rush wildly about in the stable, and one night, when he went down to look at them, he found them with tails plaited up and "all of a lather" as if they had been ridden at a great pace. The stable door was fastened, and nothing was to be seen but some "short straws" on the floor into which, he was convinced, the fairies had "turned themselves" on the sound of a mortal footstep.

Very small clay pipes are sometimes found when digging in fields or gardens, and are called "fairy pipes." One was found in a garden at Torton, Hartlebury, in 1900 . It was small, and the bowl very thick. An old labourer who saw it calsed it a "fairy pipe," and said that, when found with the stem complete, "Dotibies" "Dobie" in Ilenderson's Folk.Lore of the Northern Countics, and "Dolbies" in Allies' Antiquatios and Folk-Lore of Worcestershive, pp. 414.5 (which gives Dobies as a place name in Chaddesley Corbett). 
"they were thought a lot of." In this case the stem was missing. ${ }^{13}$

Hartlebury.

(The late) E. J. Ladbury.

"I know _-'s soul isn't at rest because I saw a black cat sitting on his grave." This was said in Worcestershire to the late Rev. E. J. Wrottesley, I892. Charlotte S. Burne.

\section{Yorkshire.}

When a storm sweeps over Ringinglow, near Sheffield, people say that Michael and his dogs are passing over.

At Bridlington they say that if a German band plays it will rain. ${ }^{14}$

They say in the East Riding that if the moon changes on Saturday bad weather will follow.

If you count seven stars for seven nights successively, you will marry the first person you kiss after the seventh night.

If you pull a tooth out in the dark, it will not hurt you.

It is unlucky to keep human hair. ${ }^{16}$

If bacon or ham is salted by a menstruous woman it will go bad. ${ }^{16}$

It is unlucky to leave a white table cloth on the table all night.

Horse-shoes nailed behind the doors of houses are called "lucky shoes" in East Yorkshire.

To prevent cramp people make a bracelet of bits of cork and attach it to the waist.

$\Lambda$ retired silversmith in Sheffield told me that every night, before getting into bed, he crossed his shoes in the shape of a $T$ to keep the cramp off.

${ }^{13}$ Cf. Brockett, Clossary of North Country Words, s.2. "Fairy-pipes"; IIartshorne, Salopia Antiqua, s.v. " Fairishes Pipes."

14 A Fifeshire boy of sixteen, a candidate in a Civil Service examination, in IDO2, in an essay on "Street Music," gave as a reason for the decreasing number of German bands in this country that people will not give them money because they bring rain. (F. A. Milne.) Also heard in London. (C. S. Burne.) Also in Dorset and Somerset, Notes and Queries, 7th S., vol. iii. (r887), pp. $306,432$.

${ }^{15}$ Also at Tutbury, Staffordshire. (C. S. Burne.)

${ }^{10}$ Universal in England, and applies to all meat. 
In Sheffeld, "burying cakes" at funerals were big, round things about a foot wide, and weighing two or three pounds. The richer people had each two biscuits given to them instead of a "burying cake."

If you wash sheets on Holy Thursday you will be lajd ont in those sheets as a corpse before the next Holy Thursday comes. ${ }^{.7}$ At Bolsterstone, a quiet hamlet about nine miles from Sheffield, it was the custom on Holy Thursday to eat custards under a tree on the green. This tree, which was known as "the custard tree," is now dead, and another tree, called "the jubilee tree," has been planted in its place. Holy Thursday is the date of Bolsterstone Feast.

S. O. Andy.

${ }^{27} \mathrm{Cr}$ Worcestershire, supra. 